Egyptian Journal of Aquatic Biology \& Fisheries

Zoology Department, Faculty of Science,

Ain Shams University, Cairo, Egypt.

ISSN $1110-6131$

Vol. 23(4): 465 - 481 (2019)

www.ejabf.journals.ekb.eg

\title{
Water Pollution Monitoring in Idku Lake (Egypt) using Phytoplankton and NSF-WQI.
}

\author{
Abdel-Aziz M. Radwan; Mahmoud A. Abdelmoneim; Afifi I. Basiony and \\ Muhammad A. El-Alfy*
}

Marine Pollution Laboratory, National Institute of Oceanography \& Fisheries, Alexandria, Egypt *corresponding author: muhammad.elalfy@yahoo.com; ma.elalfy@niof.sci.eg

\section{ARTICLE INFO}

Article History:

Received: Sept. 10, 2019

Accepted: Oct. 29, 2019

Online: Nov. 2019

Keywords:

Lake Idku

Phytoplankton

NSF-WQI

Pollution

El-Boughaz

El-Khairy drain

\begin{abstract}
Lake Idku suffers from pollution from different sources; either agricultural or municipal wastes. It faces tremendous ecological stresses due to the environmental changes and threats originated from discharges of drains. So, the aim of the present study is to assess its pollution status according to the phytoplankton species distribution and water quality index. Eight water samples were collected from the lake, preserved and analyzed. The highest total count of phytoplankton was $1,865,000$ unit $\mathrm{L}^{-1}$ is at station 4 (at the southern part of the lake), while the lowest was in front of El-Boughaz. Phytoplankton species were belonging to four divisions namely; Euglenophyceae, Chlorophyceae, Bacillariophyceae and Cyanophyceae. The most abundant genera located at the highly polluted zones were Euglena spp. and Phacus spp.; at stations 4 and 7 (in front of ElKhairy drain); this is mainly due to drain wastes. Scenedesmus spp. (Chlorophytes), Cyctotella spp. and Nitzchia spp. (Bacillariophyceae), Microcystis spp. and Chroococcus spp. were the most dominant at these stations, which are characterized by high levels of pollution. Members of euglenoids (Phacus spp. and Euglena spp.) were the most indicators to the pollution especially at stations 4 and 7 nearby drains, where they represented the main components of the total count of phytoplankton and characterized by high levels of ammonia and organic carbon. This was confirmed from the correlation matrix between phytoplankton with phosphate and ammonia. The national sanitation foundation water quality index (NSF-WQI) gives an indication to medium water quality status in lake Idku and refers to low value nearby El-Khairy drain that needs more treatment before discharging into the lake.
\end{abstract}

\section{INTRODUCTION}

In aquatic ecosystems, the phytoplankton population has been long used in the ecological evaluation as bio-indicator based on the distribution and occurrence of species at the different stations along the lake area. It used as indicators to water pollution (Brettum and Adersen, 2005). In addition to the phytoplankton have a short life span and respond quickly to the environmental changes (Zebek, 2004), therefore it may be useful indicator to determine the water quality and provide early warning signs of water deterioration conditions (Ingole et al., 2010). El-Alfy et al. (2019) stated that Egypt faces a rapidly increasing deterioration of its surface water owing to the discharges of contaminated effluents. Also different anthropogenic activities 
distributed along the coastline effect on the marine environment (El-Amier et al., 2018). Idku lake represent an open ecosystem, thus physical, chemical and biological condition in addition to the wind action depend on the drainage water which being discharged (Samaan, 1974)

Many researchers reported several studies on phytoplankton distribution in fresh water lakes as Zaghloul and Hussien (2000) who studied phytoplankton community in Lake Idku and effect of pollution; Sarwar, 1996; Tiwari and Chauhau, 2006; Somani et al. 2007; Chaudhary and Pillai, 2009; Maske et al. 2010 and Singh and Balasingh, 2011. Further studies reported the distribution of phytoplankton species with respect to the degree of water pollution like (Chattopadhyay and Banerjee, 2007; Pradhan et al. 2008 and Radwan et al. 2018).

A water quality index (WQI) describes the general situation of water bodies by changing water quality parameters levels into a numerical score using mathematical tools (Mohebbia et al., 2013). Water quality indices as National Sanitation Foundation- water quality index (NSF-WQI) are used for overall water quality assessment or for specific use. For specific assessment, the classification of water is on the basis of the type of consumption and application, for example drinking, ecosystem preservation, recreation, irrigation, and livestock (Tirkey et al., 2013).

The present study threw lights on evaluation of the lake pollution status using phytoplankton distribution as indicator through understanding the link between water quality and these species at different sites along the lake. In addition to identify the water quality within different sites using NFS-WQI. While the most prospective aim is to aid in the management process of lake.

\section{MATERIALS AND METHODS}

Lake Idku located parallel to the Mediterranean Sea at about $36 \mathrm{~km}$ east of Alexandria with an area of about $126 \mathrm{~km}^{2}$ and depth between 50 and $200 \mathrm{~cm}$. It receives drainage water through two main drains, as well as, saline water from the sea through Buoghaz El-Maadia at the northern part (Ramdani et al., 2001). Sea water invade the lake through El-Boughaz from Abu-Qir Bay which is semicircular shallow basin receiving amounts of raw industrial wastes from many factories through ElTabia Pumping station. the southern margin of the lake is characterized by density growth of hydrophytes.

Figure (1) shows sampling locations and different activities as fish farms and agricultural areas that surrounded the lake. While the latitude and longitude of these locations are described as Table (1).

The lake receives drainage water from three main drains, namely Bersik, Idku and El-Bousily, that discharges into the eastern side of lake. The maximum inflow from all drains is recorded during summer, while the minimum is in winter. An amount of $3.3 \times 10^{6} \mathrm{~m}^{3}$ per day of brackish water is introduced into Abu Qir Bay from Lake Idku through Boughaz El-Maadia (Shakweer, 2006). El-Khairy Drain is also linked to sources of drainage waters coming from El-Bousely, Idku and Damanhour sub-Drains, which transport huge drainage waters, in addition to drainage water from more than 300 fish farms (Badr and Hussein, 2010). 


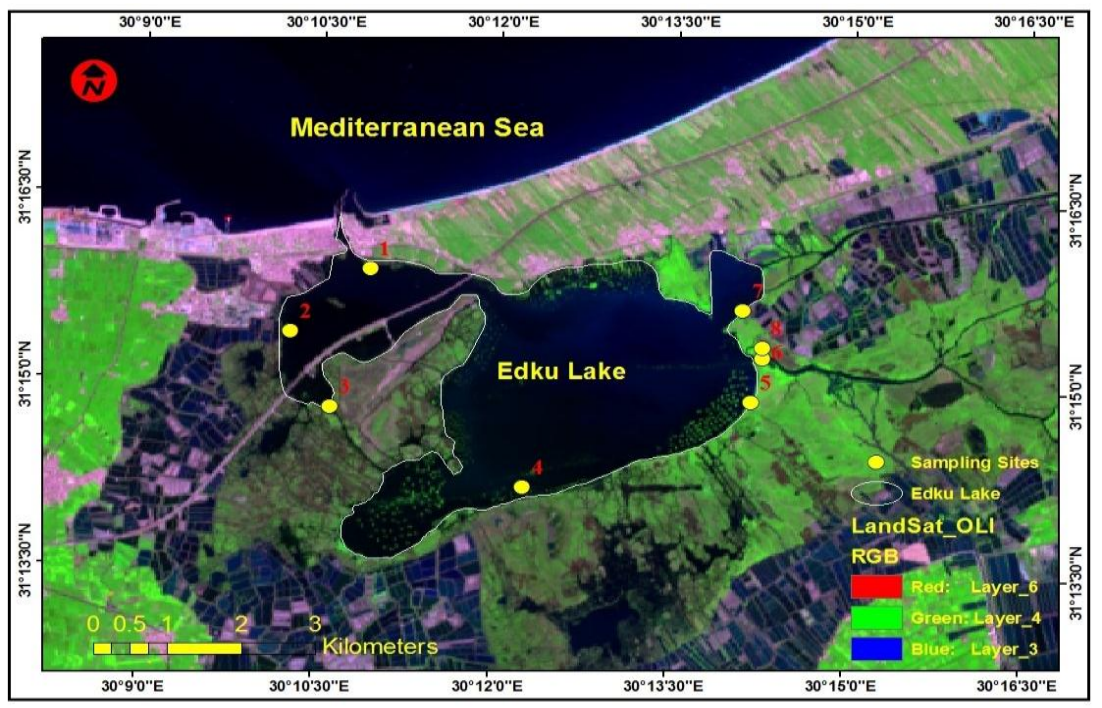

Fig. 1: A map shows sampling locations within Lake Idku

Table 1: Latitude and Longitude of sampling stations of Lake Idku

\begin{tabular}{clcc}
\hline No & \multicolumn{1}{c}{ Station } & Latitude $(\mathrm{N})$ & Longitude $(\mathrm{E})$ \\
\hline 1 & El-Boughaz & $31^{\circ} 15^{-} 54.7^{=}$ & $30^{\circ} 10^{-} 55.7^{=}$ \\
2 & Wish El-Sarf & $31^{\circ} 15^{-} 23.9^{=}$ & $30^{\circ} 10^{-} 16^{=}$ \\
3 & In front of Kamfour Drain & $31^{\circ} 14^{-} 47.8^{=}$ & $30^{\circ} 10^{-} 37^{=}$ \\
4 & South Lake & $31^{\circ} 14^{-} 11.1^{=}$ & $30^{\circ} 12^{-} 16.1^{=}$ \\
5 & In front of El-Tawilla Drain & $31^{\circ} 14^{-} 54.3^{=}$ & $30^{\circ} 14^{-} 11.2^{=}$ \\
6 & Bab El-Tawilla & $31^{\circ} 15^{-} 15.4^{=}$ & $30^{\circ} 14^{-} 16.6^{=}$ \\
7 & In front of El-Khairy Drain & $31^{\circ} 15^{-} 38.3^{=}$ & $30^{\circ} 14^{-} 5.8^{=}$ \\
8 & El-Shalashel & $31^{\circ} 15^{-} 20.6^{=}$ & $30^{\circ} 14^{-} 16.1^{=}$ \\
\hline
\end{tabular}

\section{Water Analyses}

Water depth and transparency were measured according to the methods of APHA (1999). Results of depth and transparency were expressed in $\mathrm{cm}$. Temperature $\left(\mathrm{T}^{\circ} \mathrm{C}\right)$ and dissolved oxygen (DO) are measured using Lutron YK-22 DO meter.

The $\mathrm{pH}$ value of surface water was measured using Electrical-pH meter (Model Lutron YK-2001pH meter). While Electrical conductivity (EC), Total dissolved solids (TDS in $\mathrm{mg} \mathrm{L}^{-1}$ ) and salinity were measured directly using conductivity meter (Model Corning, NY 14831 USA) and the results were expressed as ds. $\mathrm{m}^{-1}$ for EC and \%o for Salinity.

For ammonium determination, samples were fixed in the field for further measurement. Determination of nutrients $\left(\right.$ ammonium $\left(\mathrm{NH}_{4}\right)$, phosphate $\left(\mathrm{PO}_{4}\right)$, nitrite $\left(\mathrm{NO}_{2}\right)$, nitrate $\left(\mathrm{NO}_{3}\right)$ and silicate $\left.\left(\mathrm{SiO}_{4}\right)\right)$ was carried out according the methods described by Grasshoff et al. (1999).

Organic carbon (OC) was determined using rapid titration method of Walkely and Black as described by Piper (1947).

\section{Sampling and Count of Phytoplankton}

Georeferenced water samples were collected from eight locations within Idku Lake. Water samples were filtered using a phytoplankton net with pore size 20 micron for qualitative and quantitative studies. Each species was identified according to Prescott (1978), to know fresh water algae (Prescott, 1962), algae of western great lake. (Bold and Wynne, 1978) for algae in general, and Vinard (1979); Diatoms of 
North America. The count of phytoplankton species were carried out using the cell count of Haemocytometer where; one drop from the concentrated sample of phytoplankton was put on the groove of the cell count chamber, allow the concentrated sample to flow under the cover glass then allow the cell settle for about 3 minutes, the count of phytoplankton species were carried out in four large squares as follow:

The depth of counting chamber is $0.1 \mathrm{~mm}$ and the counted area is 4 squares, where area of each square in $\mathrm{mm}$ is $4 * 0.1 \mathrm{~mm}^{2}$

The counted volume $=$ area $*$ depth $=\mathrm{V}$. of 4 squares.

No. of species $\mathrm{L}^{-1}=$ number of species counted as an average of 4 squares $*$ conc. Factor $* 1000 / 0.4$

\section{Statistical Analysis}

Treatment of data was made using correlation matrix between different parameters and phytoplankton using SPSS (ver.16) program.

\section{NSF-WQI}

National Sanitation Foundation Water Quality Index (NSFWQI) is used to determine the level of water quality, based on 9 parameters such as: BOD, DO, nitrate, total phosphate, temperature, turbidity, total solids, $\mathrm{pH}$, and Fecal Coliform. In this study, only 5 parameters namely; DO, $\mathrm{pH}$, Temperature, TDS, $\mathrm{PO}_{4}$ and $\mathrm{NO}_{3}$, hence there was a modification of weight as Table (2). The modification was allowed if the water quality number reduced. Modified total weight score remained 1(Effendi et al., 2015). Weight score modification of each parameter was proportional with its original weight score (. Furthermore, the weight score (Wi) was multiplied by the subindex value (Qi) of parameter-i curve (Appendix. 1), obtained by Calculator NSFWQI Online according to the following link: https://water-research.net/index.php/watertreatment/water-monitoring/monitoring-the-quality-of-surfacewaters.

The category of NSF-WQI index was shown in Table (3). The index was calculated according to the following equation:

$N S F W Q I=\sum_{i=0}^{n} W_{i} x Q_{i}$

Where : NSF-WQI : Water Quality Index Score, Wi : The weight score, Qi : The subindex value

Table 2: New weight score (Wi) for 5 parameters on NSF-WQI

\begin{tabular}{cccccc}
\hline \multicolumn{3}{c}{ Identified Weight score } & \multicolumn{3}{c}{ Modified weight score } \\
\hline No & Dependent Parameters & Weight score & No & Studied Parameters & Weight score \\
\hline 1 & DO & 0.17 & 1 & DO & 0.255 \\
2 & pH & 0.11 & 2 & pH & 0.165 \\
3 & BOD & 0.11 & 3 & Temperature change & 0.15 \\
4 & Temperature change & 0.10 & 4 & Total Phosphate & 0.15 \\
5 & Total Phosphate & 0.10 & 5 & Nitrate & 0.15 \\
6 & Nitrate & 0.10 & 6 & Total Solids & 0.105 \\
7 & Turbidity & 0.08 & & & \\
8 & Total Solids & 0.07 & & & \\
9 & Fecal coliform & 0.16 & & & \\
& Total & 1 & & Total $\approx$ & \\
\hline
\end{tabular}


Table 3: Category of NSFWQI index

\begin{tabular}{cc}
\hline NSF-WQI & Category \\
\hline $0-25$ & Very bad \\
$26-50$ & Bad \\
$51-70$ & Medium \\
$71-90$ & Good \\
$91-100$ & Excellent \\
\hline
\end{tabular}

\section{RESULTS AND DISCUSSION}

Phytoplankton at any aquatic ecosystem plays a central role in the structure and functioning of water ecosystem. They are significant component of water ecosystems as primary producers (Ligeza and Wilk-Wozniak, 2011). Phytoplankton populations are well-known to be influenced by different discharges including urban, industrial and thermal effluents in addition to agricultural runoff and human activities (Collavini et al. 2011). Phytoplankton structure and abundance are generally more sensitive to pollution. Therefore, they are the best biological indicator of pollution in the aquatic habitat (Javed, 2006). Phytoplankton assemblages in the present study differed among drains as function of drainage basin characteristics but indicate that common changes related to the surrounding environmental factors where species are mainly of fresh or brackish water forms. So, the distribution and abundance of species was affected mainly by the different sources of pollutants. It is obvious that population of phytoplankton were more productive due to the pronounced increase of some species related to different classes especially at sites close to drains.

Table (4) indicate the dominance and flourishing species related to the class Euglenophyceae and Chlorophyceae at stations 3 and 4 recording about $780 \times 10^{3}$ cell $\mathrm{L}^{-1}$ (about $50 \%$ from the total count) at station 3 and $930 \times 10^{3}$ cell $\mathrm{L}^{-1}$ ( $55 \%$ of total count) for class Euglenophyceae at station 4. On the other hand, high count of Chlorophyceae nearly $\left(615 \times 10^{6}\right.$ cell $\left.\mathrm{L}^{-1}\right)$ was observed at station 7 infront of ElKhairy drain.

Table 4: Phytoplankton classes and their percentage of abundance in Lake Idku

\begin{tabular}{|c|c|c|c|}
\hline Station & Class & No of Units per thousand & Percentage $\%$ \\
\hline \multirow{4}{*}{$\frac{1}{\text { II }}$} & $\mathrm{A}$ & 73 & 19 \\
\hline & B & 165 & 43.1 \\
\hline & $\mathrm{C}$ & 60 & 15.7 \\
\hline & $\mathrm{D}$ & 85 & 22.2 \\
\hline \multicolumn{2}{|c|}{ No of Phytoplankton } & 383 & 100 \\
\hline \multirow{4}{*}{$=\frac{1}{5}$} & $\mathrm{~A}$ & 240 & 24 \\
\hline & $\mathrm{B}$ & 350 & 34.7 \\
\hline & $\mathrm{C}$ & 275 & 27.3 \\
\hline & $\mathrm{D}$ & 142 & 14 \\
\hline \multicolumn{2}{|c|}{ No of Phytoplankton } & 1007 & 100 \\
\hline \multirow{4}{*}{ 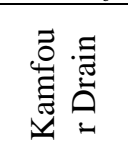 } & $\mathrm{A}$ & 513 & 36.3 \\
\hline & B & 780 & 55.2 \\
\hline & $\mathrm{C}$ & 15 & 1.1 \\
\hline & D & 105 & 7.4 \\
\hline \multicolumn{2}{|c|}{ No of Phytoplankton } & 1413 & 100 \\
\hline \multirow{4}{*}{ 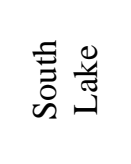 } & $\mathrm{A}$ & 261 & 14.1 \\
\hline & B & 465 & 25 \\
\hline & $\mathrm{C}$ & 930 & 50.1 \\
\hline & $\mathrm{D}$ & 200 & 10.8 \\
\hline \multicolumn{2}{|c|}{ No of Phytoplankton } & 1856 & 100 \\
\hline
\end{tabular}

Where A: Bacillariophyceae B: chlorophyceae

C: Euglenophyceae D: Cyanophyceae 
Table 4: Continued

\begin{tabular}{|c|c|c|c|}
\hline Station & Class & No of Units per thousand & Percentage $\%$ \\
\hline \multirow{4}{*}{ 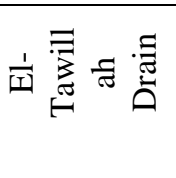 } & A & 250 & 27 \\
\hline & B & 326 & 35.4 \\
\hline & $\mathrm{C}$ & 245 & 26.6 \\
\hline & $\mathrm{D}$ & 100 & 11 \\
\hline \multicolumn{2}{|c|}{ No of Phytoplankton } & 921 & 100 \\
\hline \multirow{4}{*}{ 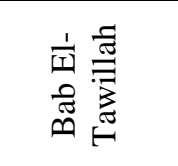 } & $\mathrm{A}$ & 163 & 29.8 \\
\hline & B & 200 & 36.7 \\
\hline & $\mathrm{C}$ & 58 & 10.6 \\
\hline & $\mathrm{D}$ & 125 & 22.9 \\
\hline \multicolumn{2}{|c|}{ No of Phytoplankton } & 546 & 100 \\
\hline \multirow{4}{*}{ 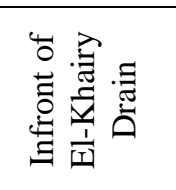 } & $\mathrm{A}$ & 380 & 21.4 \\
\hline & $\mathrm{B}$ & 615 & 34.6 \\
\hline & $\mathrm{C}$ & 570 & 42 \\
\hline & $\mathrm{D}$ & 213 & 12 \\
\hline \multicolumn{2}{|c|}{ No of Phytoplankton } & 1778 & 100 \\
\hline \multirow{4}{*}{$\frac{\bar{d}}{1} \frac{\frac{\pi}{n}}{\frac{\pi}{\tilde{E}}}$} & A & 315 & 32.1 \\
\hline & B & 310 & 31.6 \\
\hline & $\mathrm{C}$ & 235 & 23.9 \\
\hline & D & 122 & 12.4 \\
\hline \multicolumn{2}{|c|}{ No of Phytoplankton } & 982 & 100 \\
\hline
\end{tabular}

Where A: Bacillariophyceae B: Chlorophyceae C: Euglenophyceae D: Cyanophyceae

The Euglenoids were the main productive and abundant among the standing crop of phytoplankton at station 4 (south the lake) and station 7 (at El-Khairy drain) where heavy load of organic matters were discharged led to the blooming of the species related to this class which recorded low count far away from drains. Stations 4 and 7 characterized by high levels of ammonia and organic carbon. The recorded species belong to this class were seven namely; Euglen acus, E. gracilis, E. granulata, E. Promxia, Phucus longicauda, Ph. pleuronectes and Ph. macrostigma. The abundance of these species at station 4 was mainly due to heavy load of drainage water either sewage or fish farms. This is agreed with Amphorn and Wanninee (2013). Radwan et al. (2018) stated that rivers and lakes with stagnant and weak water currents always contain Euglenoids species as Euglena spp. and Phacus spp. consider indicator to organic pollution.

Concerning the distribution of chlorophytes species within different stations of the lake. It was the most productive at station 3 (in front of kamfour drain) constituting about $55.1 \%$ from the total count of phytoplankton which attributed to the huge load of organic effluents from sewage and fish farms. The genus Scenedesmus was the most abundant among the chlorophytes genera. Also the species Scenedesmus dimorphus was the most dominant in the group of Scenedesmus. The flourish of Scenedesmus species at this station was mainly due to the organic pollution discharges, this is agreed with Radwan et al. (2018) who mentioned the same reasons for the flourishing of Scenedesmus species.

The distribution of Bacillariophyceae species were dominant at station 3 (infront of Kamfour drain) representing about $63.3 \%$ of the total count of phytoplankton followed by station 7 (infront of El-Khairy drain) constituting about $21.4 \%$. The most abundant genera at these stations was Cyclotella spp. since these stations were 
affected by drainage water. The genus Cyclotella spp. was represented by two species namely; Cyclottela meneghiniana and Cyclottela kutzingiana. While the other genera of Bacillariophyceae were low in count with take into consideration that genus Nitzschia spp. was the second represented into two species namely; Nitzschia longissiam and Nitzschia closterium. These observations were in agreement with Sabatar and Sabatar (1988) who mentioned that the genus Cyclotella can tolerate different pollution conditions.

Abdalla et al. (1991) found that the species of Cyclotella and Nitzschia flourish with the increase of organic pollution, other investigations were carried out by AbdelHamid (1986) who reported that the distribution of these genera and the high count was influenced by the organic load. Also Mukherjee et al. (2010) noticed that the blooms of diatoms occurred in Ranchi lake were due to organic matter. Radwan et al. (2018) found that the flourishment of two genera of Bacillariophyceae as well as the euglenoides were restricted in high density in front of the drains in Lake Burullus.

From check list in appendix, the cyanophytes recorded the highest count $(213,000$ unit/L) at station 7 as compared with other stations. The members of Cyanophyceae were high diversity especially stations nearby drains. The number of cyanophytes decrease gradually with further away from drains (Table $2 \&$ Figure 2). The genera of chroococcus spp. and microcystis spp. were the most productive among the Cyanophytes at stations 3, 4, 5 and 7 with wastes from municipal and fish farms. This is agreed with Radwan (1994) who reported that the flourish of Cyanophytes were affected mainly by organic wastes originated from drains. Wang and Zhang (1993) reported that the dominant species of blue green algae especially Microcystis spp. indicated that the lake was suffered from the effects of pollution. The study of Rodrigues et al. (1995) indicated that the pollutant and high levels of nutrient (eutrophication process) contributed to increase in the number of blur green algae in lakes. Radwan et al. (2018) revealed that the genera of microcystis spp. and chroococcus spp. were the most diverse at stations nearby drains of Lake Burullus . Different species of phytoplankton within each station were shown in Appendix 2.

Table (5) indicate the different concentrations of parameters within Idku Lake. While the correlation matrix as shown in Table (6) between phytoplankton, Euglenophyceae and different nutrients showed significant correlation between the total count of phytoplankton and $\mathrm{PO}_{4} \quad(\mathrm{r}=0.739)$ and between total count of Euglenophyceae with $\mathrm{NH}_{4}(\mathrm{r}=0.905)$. As nutrients are limiting factors for growth for algae and reasons for eutrophication in coastal lakes and reservoirs as a result to agricultural drains. 
Table 5: Physiochemical parameters at different stations of Lake Idku

\begin{tabular}{ccccccccccccccc}
\hline $\mathrm{St}$ & $\mathrm{T}^{\circ} \mathrm{C}$ & $\begin{array}{c}\mathrm{DO} \\
\mathrm{mg} \mathrm{L}^{-1}\end{array}$ & $\begin{array}{c}\text { Depth } \\
\mathrm{cm}\end{array}$ & $\begin{array}{c}\text { Trans. } \\
\mathrm{cm}\end{array}$ & $\mathrm{pH}$ & $\begin{array}{c}\mathrm{EC} \\
\mathrm{mscm}^{-1}\end{array}$ & $\begin{array}{c}\mathrm{S} \\
\% \text { o }\end{array}$ & $\begin{array}{c}\mathrm{TDS} \\
\mathrm{mgL}^{-1}\end{array}$ & $\begin{array}{c}\mathrm{PO}_{4} \\
\mu \mathrm{gL}^{-1}\end{array}$ & $\begin{array}{c}\mathrm{NH}_{4} \\
\mu \mathrm{gL}^{-1}\end{array}$ & $\begin{array}{c}\mathrm{NO}_{2} \\
\mu \mathrm{gL}^{-1}\end{array}$ & $\begin{array}{c}\mathrm{NO}_{3} \\
\mu \mathrm{gL}^{-1}\end{array}$ & $\begin{array}{c}\mathrm{SiO}_{4} \\
\mu \mathrm{gL}^{-1}\end{array}$ & $\begin{array}{c}\mathrm{OC}^{2} \\
\mathrm{mgG}^{-1}\end{array}$ \\
\hline 1 & 14.4 & 12.4 & 150 & 30 & 8.5 & 18.3 & 10 & 9920 & 260.6 & 234.9 & 187.7 & 1241.35 & 1161.2 & 50.7 \\
2 & 15.5 & 15.5 & 60 & 25 & 9.1 & 28.1 & 16 & 15720 & 122.5 & 150.1 & 187.7 & 509.9 & 209.7 & 150 \\
3 & 14 & 12.5 & 50 & 30 & 8.9 & 35.8 & 20.8 & 20400 & 76.6 & 88.6 & 301.5 & $\mathrm{nd}$ & 1752.6 & 97.5 \\
4 & 15 & 15.7 & 80 & 30 & 9 & 36.6 & 21.4 & 20600 & 43.8 & 730.6 & 148.3 & 500.5 & 1817.1 & 156 \\
5 & 14.3 & 9.2 & 70 & 30 & 8.4 & 14.04 & 7.6 & 7460 & 56.3 & 329.6 & 145.4 & 681.6 & 3655.7 & 58 \\
6 & 13.6 & 6.1 & 130 & 25 & 8.3 & 12.24 & 6.6 & 6440 & 79.6 & 293.9 & 77.3 & 1101.75 & 3026.7 & 50.7 \\
7 & 14.7 & 3.7 & 150 & 30 & 8.3 & 8.88 & 4.6 & 4560 & 89.4 & 581.8 & 112.3 & 836.2 & 2860 & 13.65 \\
8 & 13.5 & 6.1 & 95 & 25 & 8.2 & 12.02 & 6.4 & 6300 & 138.7 & 362.8 & 101.3 & 514.65 & 3478.3 & 70.2 \\
\hline
\end{tabular}

T: Temperature, Trans: Transparency, EC: Electrical conductivity, S: Salinity, TDS: total dissolved salts, DO: Dissolved oxygen,

$\mathrm{PO}_{4}$ : Phosphate, $\mathrm{NO}_{2}$ : Nitrite, $\mathrm{NO}_{3}$ : Nitrate, $\mathrm{SiO}_{4}$ : Silicate, $\mathrm{OC}$ : organic carbon in sediments and nd: non-detected

Table 6: Pearson-moment correlation between different parameters and total count of phytoplankton and Euglenophyceae

\begin{tabular}{|c|c|c|c|c|c|c|c|c|c|c|c|c|c|c|}
\hline Para. & Temp & DO & Depth & Trans & $\mathrm{pH}$ & Sal & $\mathrm{PO}_{4}$ & $\mathrm{NH}_{4}$ & $\mathrm{NO}_{2}$ & $\mathrm{NO}_{3}$ & $\mathrm{SiO}_{4}$ & $\mathrm{OC}$ & T_Phyto & T_Eugl \\
\hline Temp & 1 & & & & & & & & & & & & & \\
\hline Do & 0.611 & 1 & & & & & & & & & & & & \\
\hline Depth & -0.197 & -0.566 & 1 & & & & & & & & & & & \\
\hline Trans & 0.212 & 0.167 & 0.064 & 1 & & & & & & & & & & \\
\hline $\mathrm{pH}$ & 0.702 & $0.909 * *$ & -0.641 & 0.126 & 1 & & & & & & & & & \\
\hline Sal & 0.434 & $0.864 * *$ & -0.666 & 0.246 & $0.921 * *$ & 1 & & & & & & & & \\
\hline $\mathrm{PO}_{4}$ & -0.046 & 0.068 & 0.491 & -0.062 & -0.179 & -0.239 & 1 & & & & & & & \\
\hline $\mathrm{NH}_{4}$ & 0.211 & -0.165 & 0.299 & 0.299 & -0.128 & -0.068 & -0.365 & 1 & & & & & & \\
\hline $\mathrm{NO}_{2}$ & 0.216 & 0.614 & -0.544 & 0.42 & 0.653 & $0.717 *$ & 0.092 & -0.541 & 1 & & & & & \\
\hline $\mathrm{NO}_{3}$ & -0.089 & -0.344 & $0.852 * *$ & -0.075 & -0.539 & -0.650 & 0.509 & 0.151 & -0.605 & 1 & & & & \\
\hline $\mathrm{SiO}_{4}$ & -0.689 & $-0.786^{*}$ & 0.194 & 0.005 & $-0.803 *$ & -0.633 & -0.377 & 0.32 & -0.569 & 0.113 & 1 & & & \\
\hline $\mathrm{OC}$ & 0.542 & $0.860 * *$ & $-0.717^{*}$ & -0.156 & $0.883^{* *}$ & $0.846^{* *}$ & -0.246 & 0.005 & 0.374 & -0.546 & -0.608 & 1 & & \\
\hline T_Phyto & -0.043 & 0.163 & 0.312 & 0.526 & 0.004 & 0.096 & $0.739 *$ & -0.285 & 0.544 & 0.137 & -0.347 & -0.259 & 1 & \\
\hline T_Eugl & 0.54 & 0.172 & -0.013 & 0.291 & 0.267 & 0.252 & -0.438 & $0.905 * *$ & -0.284 & -0.117 & 0 & 0.359 & -0.324 & 1 \\
\hline
\end{tabular}

**. Correlation is significant at the 0.01 level (2-tailed). *. Correlation is significant at the 0.05 level (2-tailed).

Temp: temperature, DO: dissolved oxygen, Trans: Transparency, sal: Salinity, T_Phyto: total count phytoplankton, T_Eugl: Total conut of Euglenophyceae. 
According to Table (7), it is indicated that water quality in the lake categorized from medium at all sites to good quality only in site 5. It is obvious that the lowest water quality or value was in station 7 at El-Khairy drain that discharge huge amount of waste waters inside the lake. While the general water quality status during the period of study refer to medium water quality.

Table 7: Category of lake water quality according to calculation of NSF-WQI

\begin{tabular}{ccc}
\hline Station & Value of NSF-WQI & Water Quality \\
\hline 1 & 67.79 & Medium \\
2 & 55.59 & Medium \\
3 & 67.43 & Medium \\
4 & 56.84 & Medium \\
5 & 70.76 & Good \\
6 & 62.07 & Medium \\
7 & 54.12 & Medium \\
8 & 62.43 & Medium
\end{tabular}

NSF-WQI: National Sanitation Foundation-Water Quality Index

Appendix 1: Weighting curve charts
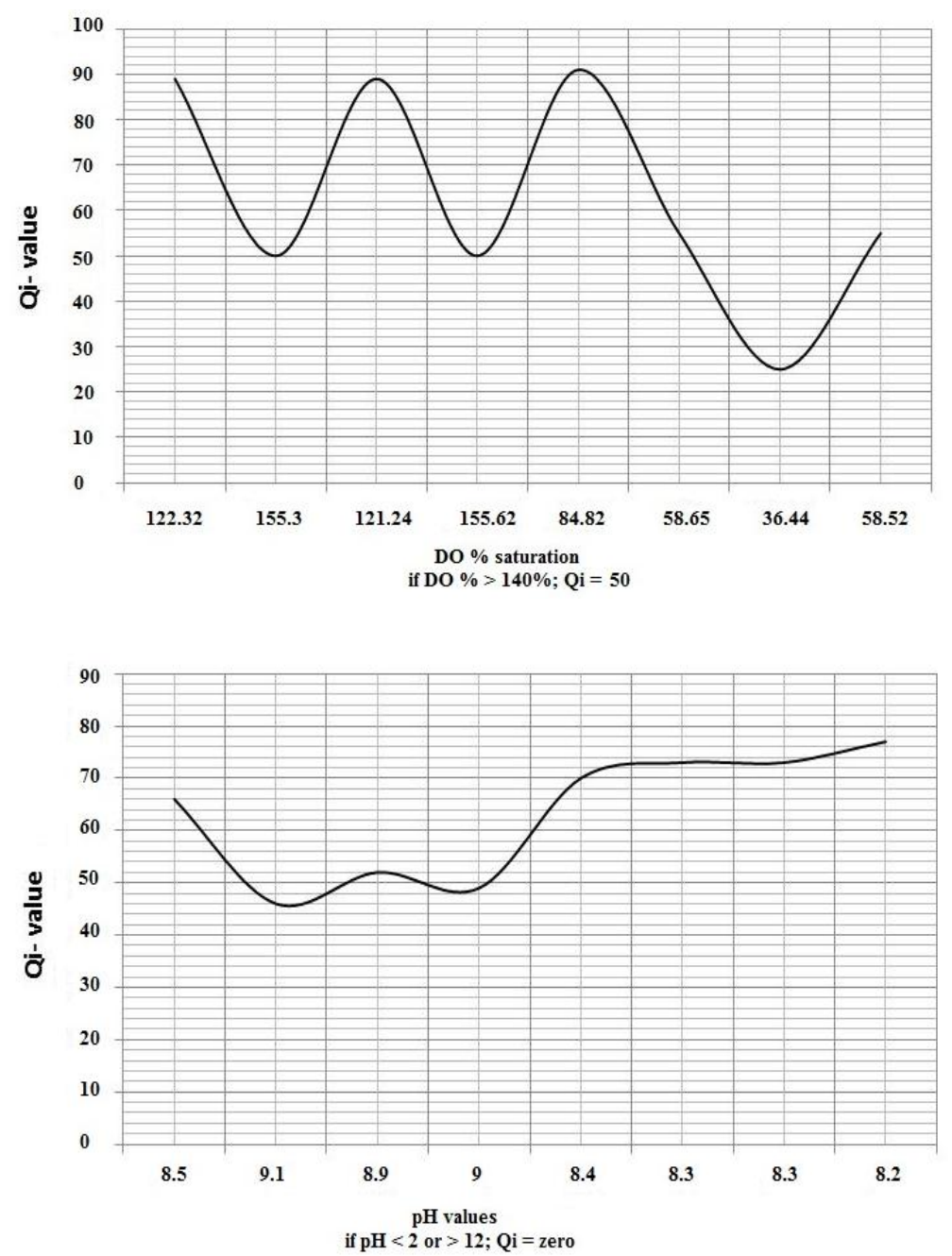

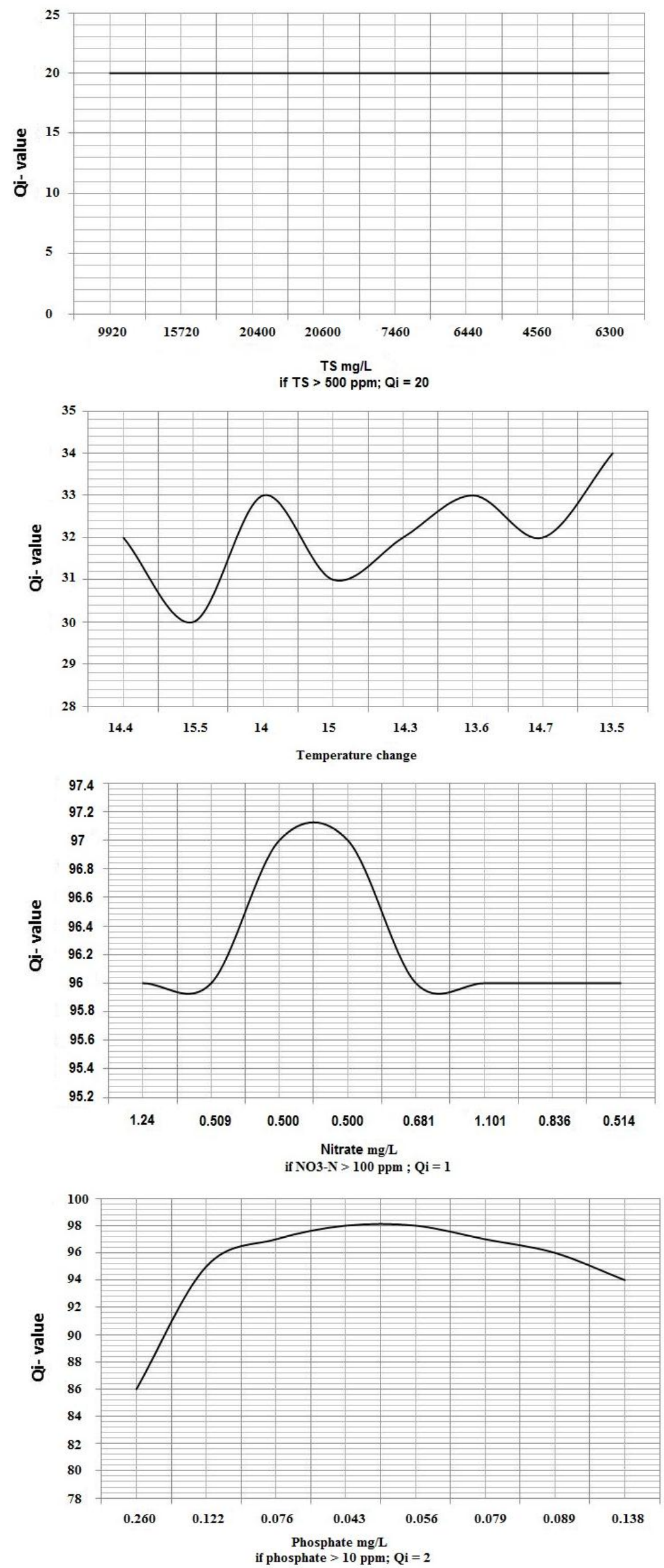
Appendix 2: Checklist of phytoplankton species identified and counted at the selected stations of lake Idku

\begin{tabular}{|c|c|}
\hline Station (1): El-Boughaz & Cell L ${ }^{-1}$ \\
\hline $\begin{array}{cl}\text { A- } & \text { Bacillariophyceae } \\
& \bullet \quad \text { Cyclotella menghiniana } \\
\bullet & \text { Cyclotella kutzingiana } \\
\bullet & \text { Nitzchia closterium } \\
& \text { Cocconies placentala } \\
& \text { Navicula sp. } \\
\end{array}$ & $\begin{array}{l}40000 \\
20000 \\
3000 \\
6000 \\
\underline{4000} \\
73000\end{array}$ \\
\hline $\begin{array}{cl}\text { B- } & \text { Chlorophyceae } \\
& \quad \text { Scenedesmus quadricauda } \\
\bullet & \text { Scenedesmus acuminatus } \\
\bullet & \text { Scenedesmus bijugalus } \\
\bullet & \text { Chlorella vulgaris } \\
\bullet & \text { Scenedesmus dimorphus } \\
\end{array}$ & $\begin{array}{r}35000 \\
50000 \\
20000 \\
10000 \\
\underline{50000} \\
165000 \\
\end{array}$ \\
\hline $\begin{aligned} \text { C- } & \text { Euglenophyceae } \\
& \bullet \quad \text { Phacus longicauda } \\
& \bullet \quad \text { Phacus macrostigma } \\
& \bullet \quad \text { Euglena acus }\end{aligned}$ & $\begin{array}{r}30000 \\
10000 \\
20000 \\
60000 \\
\end{array}$ \\
\hline $\begin{array}{cc}\text { D- } & \text { Cyanophyceae } \\
& \bullet \quad \text { Oscillatoria formosa } \\
& \bullet \quad \text { Oscillatoria limnetica } \\
& \bullet \quad \text { Microcystis flos-aquae } \\
& \bullet \quad \text { Chroococcus dispersus }\end{array}$ & $\begin{array}{l}20000 \\
15000 \\
35000 \\
15000 \\
85000 \\
\end{array}$ \\
\hline Station (2): Wish El-Serf & Cell L ${ }^{-1}$ \\
\hline $\begin{array}{cl}\text { A- Bacillariophyceae } \\
\qquad \quad \text { Cyclotella menghiniana } \\
\bullet \quad \text { Cyclotella kutzingiana } \\
\bullet \quad \text { Cocconies placentala } \\
\bullet \quad \text { Nitzchia closterium } \\
\bullet \quad \text { Navicula } \text { sp. }\end{array}$ & $\begin{array}{r}120000 \\
50000 \\
20000 \\
40000 \\
10000 \\
240000 \\
\end{array}$ \\
\hline $\begin{array}{l}\text { B- Chlorophyceae } \\
\bullet \quad \text { Scenedesmus quadricauda } \\
\bullet \quad \text { Scenedesmus acuminatus } \\
\bullet \quad \text { Scenedesmus bijugalus } \\
\bullet \quad \text { Chlorella vulgaris } \\
\bullet \quad \text { Ankistrodesmus falcatus varacicularis } \\
\bullet \quad \text { Scenedesmus dimorphus }\end{array}$ & $\begin{array}{r}60000 \\
70000 \\
55000 \\
35000 \\
40000 \\
90000 \\
350000 \\
\end{array}$ \\
\hline $\begin{aligned} & \text { C- } \text { Euglenophyceae } \\
& \bullet \quad \text { Phacus longicauda } \\
& \bullet \quad \text { Phacus macrostigma } \\
& \bullet \quad \text { Euglena granulate } \\
& \bullet \quad \text { Euglena gracilis } \\
& \text { Euglena acus } \\
&\end{aligned}$ & $\begin{array}{l}80000 \\
60000 \\
20000 \\
45000 \\
\underline{70000} \\
275000 \\
\end{array}$ \\
\hline $\begin{array}{c}\text { D- Cyanophyceae } \\
\bullet \quad \text { Microcystis aeriogenosa } \\
\bullet \quad \text { Microcystis flos-aquae } \\
\bullet \quad \text { Oscillatoria formosa } \\
\bullet \quad \text { Oscillatoria limnetica } \\
\bullet \quad \text { Chroococcus disperses } \\
\bullet \quad \text { Merismopedia punctata }\end{array}$ & $\begin{array}{r}60000 \\
30000 \\
10000 \\
15000 \\
25000 \\
\underline{2000} \\
\underline{42000} \\
\end{array}$ \\
\hline Station (3): Infront of Kamfour Drain & Cell L ${ }^{-1}$ \\
\hline $\begin{aligned} \text { A- } & \text { Bacillariophyceae } \\
& \bullet \quad \text { Cyclotella menghiniana } \\
& \bullet \quad \text { Cyclotella kutzingiana } \\
& \bullet \quad \text { Cocconies placentala } \\
& \bullet \quad \text { Nitzchia longissima (Breb.) Ralfs }\end{aligned}$ & $\begin{array}{c}200000 \\
180000 \\
25000 \\
35000\end{array}$ \\
\hline
\end{tabular}




\begin{tabular}{|c|c|c|}
\hline . & $\begin{array}{ll}\text { - } & \text { Nitzchia closterium Smith } \\
\text { - } \quad \text { Navicula viridula } \\
\text { - } \quad \text { Navicula sp. }\end{array}$ & $\begin{array}{c}58000 \\
10000 \\
\underline{5000} \\
513000 \\
\end{array}$ \\
\hline B- Chl & $\begin{array}{l}\text { orophyceae } \\
\text { - } \quad \text { Scenedesmus dimorphus } \\
\text { - } \quad \text { Scenedesmus quadricauda } \\
\text { - } \quad \text { Scenedesmus acuminatus } \\
\text { - } \quad \text { Scenedesmus bijugalus var alternans Hansg } \\
\text { - } \quad \text { Chlorella vulgaris } \\
\text { - } \quad \text { Ankistrodesmus falcatus var acicularis } \\
\end{array}$ & $\begin{array}{c}210000 \\
90000 \\
160000 \\
100000 \\
80000 \\
30000 \\
40000 \\
780000\end{array}$ \\
\hline \multicolumn{3}{|c|}{ C- Euglenophyceae } \\
\hline D- Cya & $\begin{array}{l}\text { nophyceae } \\
\text { - } \quad \text { Microcystis incerta } \text { Lemm } \\
\text { - } \quad \text { Oscillatoria formosa } \text { Bory } \\
\text { - } \quad \text { Chroococcus disperssus (Keissl.) Lemmermann }\end{array}$ & $\begin{array}{r}20000 \\
5000 \\
80000 \\
105000 \\
\end{array}$ \\
\hline Station (4): $S$ & South Lake & Cell L $^{-1}$ \\
\hline A- Bac & $\begin{array}{l}\text { illariophyceae } \\
\text { - } \quad \text { Cyclotella menghiniana } \\
\text { - } \quad \text { Cyclotella kutzingiana } \\
\text { - } \quad \text { Cocconies placentala } \\
\text { - } \quad \text { Nitzchia longissima } \\
\text { - } \quad \text { Melosira sp. }\end{array}$ & $\begin{array}{r}60000 \\
58000 \\
52000 \\
56000 \\
\underline{3000} \\
261000 \\
\end{array}$ \\
\hline B- Chlc & $\begin{array}{l}\text { - } \quad \text { Scenedesmus quadricauda } \\
\text { - } \quad \text { Scenedesmus acuminatus } \\
\text { - } \quad \text { Scenedesmus bijugalus } \\
\text { - } \quad \text { Anlorella vulgaris } \\
\text { - } \quad \text { Ankistrodesmus falcatus var acicularis } \\
\text { - } \quad \text { Scenedesmus falcatus var spiriliforms } \\
\text { - } \quad \text { Pediastrum simplex } \\
\text { - Botryococcus braunii Kuetzing } \\
\end{array}$ & $\begin{array}{r}110000 \\
50000 \\
40000 \\
35000 \\
60000 \\
80000 \\
70000 \\
20000 \\
40000 \\
465000 \\
\end{array}$ \\
\hline C- Eug & $\begin{array}{l}\text { lenophyceae } \\
\text { - } \quad \text { Phacus longicauda } \\
\text { - } \quad \text { Phacus macrostigma } \\
\text { - } \quad \text { Euglena granulate } \\
\text { - } \quad \text { Euglena gracilis } \\
\text { - } \quad \text { Euglena acus } \\
\text { - Euglena proxima }\end{array}$ & $\begin{array}{c}120000 \\
50000 \\
70000 \\
110000 \\
130000 \\
260000 \\
190000 \\
930000 \\
\end{array}$ \\
\hline D- Cya & $\begin{array}{l}\text { nophyceae } \\
\text { - } \quad \text { Microcystis aeriogenosa } \\
\text { - } \quad \text { Microcystis incerta } \\
\text { - } \quad \text { Chroococcus disperses }\end{array}$ & $\begin{array}{r}55000 \\
50000 \\
35000 \\
60000 \\
200000 \\
\end{array}$ \\
\hline Station (5): & El-Tawilla Drain & Cell L'-1 \\
\hline $\mathrm{A}-\mathrm{Bac}$ & $\begin{array}{l}\text { illariophyceae } \\
\text { - } \quad \text { Cyclotella menghiniana } \\
\text { - } \quad \text { Nyclotella kutzingiana } \\
\text { - } \quad \text { Synedra tabulate } \\
\text { - } \quad \text { Navicula sp. } \\
\text { - } \quad \text { Cocconeis placentula }\end{array}$ & $\begin{array}{c}110000 \\
90000 \\
20000 \\
10000 \\
5000 \\
\underline{15000} \\
250000 \\
\end{array}$ \\
\hline
\end{tabular}




\begin{tabular}{|c|c|}
\hline $\begin{array}{l}\text { B- Chlorophyceae } \\
\bullet \quad \text { Scenedesmus quadricauda } \\
\bullet \quad \text { Scenedesmus acuminatus } \\
\bullet \quad \text { Scenedesmus bijugalus } \\
\bullet \quad \text { Ankistrodesmus falcatus var acicularis } \\
\bullet \quad \text { Ankistrodesmus falcatus var spiriliforms } \\
\bullet \quad \text { Scenedesmus dimorphus }\end{array}$ & $\begin{array}{l}70000 \\
90000 \\
50000 \\
20000 \\
30000 \\
\underline{66000} \\
326000\end{array}$ \\
\hline $\begin{array}{l}\text { C- } \text { Euglenophyceae } \\
\qquad \quad \text { Phacus longicauda } \\
\bullet \quad \text { Phacus macrostigma } \\
\bullet \quad \text { Euglena acus } \\
\bullet \quad \text { Euglena proxima }\end{array}$ & $\begin{array}{r}55000 \\
40000 \\
90000 \\
60000 \\
245000\end{array}$ \\
\hline $\begin{array}{cl}\text { D- Cyanophyceae } \\
\bullet \quad \text { Merismopedia tenuissima } \\
\bullet \quad \text { Chroococcus limneticus } \\
\bullet \quad \text { Chroococcus disperses }\end{array}$ & $\begin{array}{r}20000 \\
35000 \\
45000 \\
100000\end{array}$ \\
\hline Station (6): Bab El-Tawillah & Cell L ${ }^{-1}$ \\
\hline $\begin{array}{cl}\text { A- } & \text { Bacillariophyceae } \\
& \bullet \quad \text { Cyclotella menghiniana } \\
& \text { Cyclotella kutzingiana } \\
& \text { Navicula sp. } \\
& \text { Synedra ulna } \\
& \text { Cocconeis placentula } \\
& \text { Nitzschia longissima } \\
& \text { Nitzschia } \text { sp. } \\
& \text { Navicula } \text { sp. } \\
\end{array}$ & $\begin{array}{l}80000 \\
50000 \\
30000 \\
8000 \\
10000 \\
6000 \\
2000 \\
\underline{4000} \\
163000\end{array}$ \\
\hline $\begin{array}{cl}\text { B- } & \text { Chlorophyceae } \\
& \bullet \quad \text { Scenedesmus quadricauda } \\
& \bullet \quad \text { Scenedesmus bijugalus } \\
& \bullet \quad \text { Ankistrodesmus falcatus var acicularis } \\
& \bullet \quad \text { Ankistrodesmus falcatus var spiriliforms } \\
& \bullet \quad \text { Scenedesmus dimorphus } \\
& \text { Chlorella } \mathrm{sp} . \\
\end{array}$ & $\begin{array}{r}35000 \\
45000 \\
15000 \\
25000 \\
50000 \\
\underline{30000} \\
200000 \\
\end{array}$ \\
\hline $\begin{array}{c}\text { C- Euglenophyceae } \\
\qquad \quad \text { Phacus longicauda } \\
\bullet \quad \text { Phacus macrostigma } \\
\bullet \quad \text { Euglena acus } \\
\bullet \quad \text { Euglena proxima } \\
\end{array}$ & $\begin{array}{c}15000 \\
10000 \\
25000 \\
\underline{8000} \\
58000 \\
\end{array}$ \\
\hline $\begin{array}{cl}\text { D- } & \text { Cyanophyceae } \\
\bullet & \text { Merismopedia tenuissima } \\
\bullet & \text { Microcystis aeriogenosa } \\
\bullet & \text { Chroococcus limneticus } \\
\bullet & \text { Chroococcus disperses } \\
\end{array}$ & $\begin{array}{l}35000 \\
20000 \\
30000 \\
40000 \\
125000 \\
\end{array}$ \\
\hline Station (7): Infront of El-Khairy drain & Cell L ${ }^{-1}$ \\
\hline $\begin{array}{cl}\text { A- } & \text { Bacillariophyceae } \\
& \bullet \quad \text { Cyclotella menghiniana } \\
& \bullet \quad \text { Cyclotella kutzingiana } \\
\bullet & \text { Cocconeis placentula } \\
& \bullet \quad \text { Nitzschia longissima } \\
& \bullet \quad \text { Nitzschia closterium } \\
\end{array}$ & $\begin{array}{c}85000 \\
140000 \\
40000 \\
55000 \\
\underline{60000} \\
380000\end{array}$ \\
\hline
\end{tabular}




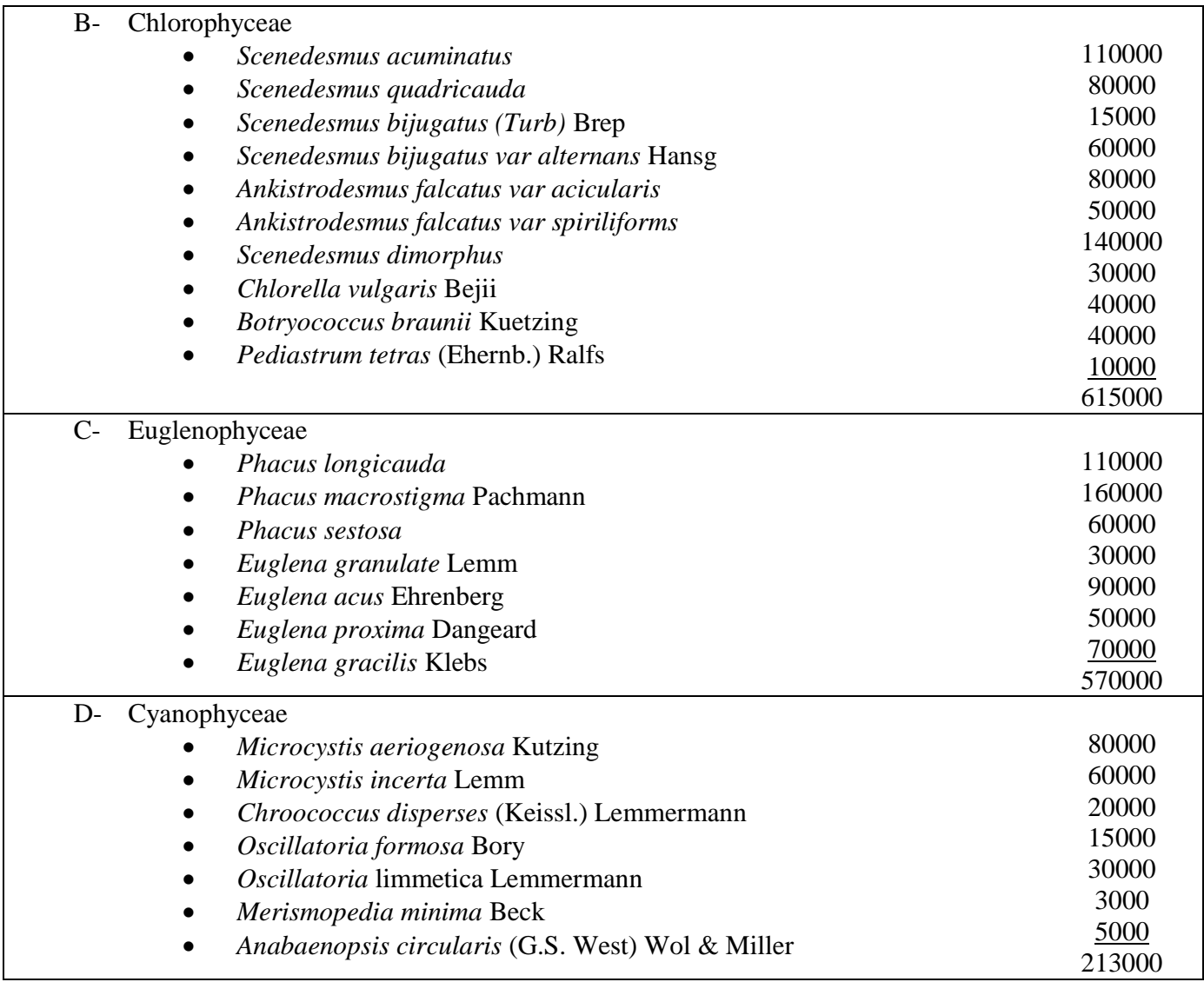

\begin{tabular}{|c|c|}
\hline Station (8): El-Shalashel & Cell L ${ }^{-1}$ \\
\hline $\begin{array}{cl}\text { A- Bacillariophyceae } \\
\\
\bullet \quad \text { Cyclotella menghiniana } \\
\bullet \quad \text { Cyclotella kutzingiana } \\
\bullet \quad \text { Nitzschenia placentula } \\
\bullet \quad \text { Nitzschia } \text { sp. } \\
\bullet \quad \text { Navicula } \text { sp. }\end{array}$ & $\begin{array}{r}90000 \\
60000 \\
95000 \\
30000 \\
25000 \\
\underline{15000} \\
315000\end{array}$ \\
\hline $\begin{aligned} & \text { B- } \text { Chlorophyceae } \\
& \bullet \quad \text { Scenedesmus acuminatus } \\
& \bullet \text { Scenedesmus quadricauda } \\
& \bullet \text { Scenedesmus dimorphus } \\
& \bullet \text { Scenedesmus bijugatus var alternans } \\
& \bullet \text { Ankistrodesmus falcatus var acicularis } \\
& \bullet \text { Chlorella } \text { sp. } \\
& \bullet \text { Botryococcus braunii } \\
&\end{aligned}$ & $\begin{array}{r}60000 \\
50000 \\
80000 \\
40000 \\
55000 \\
10000 \\
15000 \\
310000 \\
\end{array}$ \\
\hline $\begin{array}{c}\text { C- } \quad \text { Euglenophyceae } \\
\bullet \quad \text { Phacus longicauda } \\
\bullet \quad \text { Phacus macrostigma } \\
\bullet \quad \text { Phacus sestosa } \\
\bullet \quad \text { Euglena acus } \\
\bullet \quad \text { Euglena proxima Dangear } \\
\end{array}$ & $\begin{array}{r}50000 \\
80000 \\
25000 \\
60000 \\
\underline{20000} \\
235000 \\
\end{array}$ \\
\hline $\begin{array}{c}\text { D- Cyanophyceae } \\
\bullet \quad \text { Microcystis aeriogenosa } \\
\bullet \quad \text { Microcystis incerta } \\
\bullet \quad \text { Chroococcus dispersus } \\
\bullet \quad \text { Oscillatoria formosa } \\
\bullet \quad \text { Oscillatoria limnetica } \\
\bullet \quad \text { Anabismopedia minima } \\
\bullet\end{array}$ & $\begin{array}{r}30000 \\
40000 \\
15000 \\
10000 \\
20000 \\
5000 \\
\underline{2000} \\
122000\end{array}$ \\
\hline
\end{tabular}




\section{CONCLUSIONS}

It is concluded that the increase of agricultural and sewage wastewater aid in the distribution of phytoplankton species as it was observed by the flourishing and abundance at the outlets of drains that contain high load of organic matters. Using index to water quality summarize the lake status and give distinguished interpretation for the state of it based on measured parameters. The water from drains needed to further treatment and management.

\section{REFERENCES}

Abdalla, R.R.; Samaan, A.A. and Ghabrial, M.G. (1991). Eutrophication in Lake Mariut. Bull. Nat. Ins. Ocean. \& Fish., ARE,17(1): 157-166.

Abdel-Hamid, M. I. (1986). Ecological studies on algal pollution of Damietta branch and the possibility of their use as water pollution indicator. M.Sc. Thesis, Botany Department, Mansoura university, 260 PP.

Amphorn, S. and Wanninee, C. (2013). Phytoplankton as bioindicator of water quality in the freshwater area of Pak Phanang River Basin (Southern Thailand). Chiang Mai. J. Sci., 40(3):344-355.

APHA. (1999). Standard methods. 20th edition. American Public Health Association, Washington, DC., USA.

Badr, N.B.E. and Hussein, M.M.A. (2010). An Input/ Output Flux Model of Total Phosphorous in Lake Idku, a Northern Eutrophic Nile Delta Lake. Global J. of Environ. Res., 4(2): 64-75.

Bold, H.C. and Wynne, M.J. (1978). Introduction to the algae structure and reproduction prentice. Hall. Inc. Engl wood Cliffs, New Jersy 07632. USA.

Brettum, P. and Andersen, T. (2005). The use of phytoplankton as indicator of water quality. NIVA report SNO 4818-2004.

Chattopadhyay, C. and Banerjee, T.C. (2007). Temporal changes in environmental characteristics and diversity of net phytoplankton in a freshwater lake. Turk. J. Bot., 31: 287-296.

Chaudhary, R. and Pillai, R.S. (2009). Algal biodiversity and related physic-chemical parameters in Sasthamocottah Lake, Kerala (India). J. Enviro. Res. and dev., 3:3.

Collavini, F.; Zonta, R.; Bettiol, C.; Fagarazzi, O.E. and Zaggia, L. (2011). Metal and nutrients loads from the drainage basin to the Venice Lagoon. Determination of the polluted load discharged into the Venice by Drainage Basin. Venice, July. pp. 48-55.

Effendi, H.; Romanto and Wardiatno, Y. (2015). Water quality status of Ciambulawung River, Banten Province, based on pollution index and NSFWQI. Pro. Environ. Sci., 24: 228 - 237.

El-Alfy, M. A.; Hasballah, A. F.; Abd El-Hamid, H.T. and El-Zeiny, A.M. (2019). Toxicity assessment of heavy metals and organochlorine pesticides in freshwater and marine environments, Rosetta area, Egypt using multiple approaches. Sust. Environ. Res., 29:19.

El-Amier, Y.A.; Alghanem, S.M. and El-Alfy M.A. (2018). Ecological Risk Assessment of Heavy Metal Pollution in Top soil of Mediterranean Coast: A Case Study of Mareotis Coast, Egypt. Biosci. Res., 15(3): 2626-2639.

Grasshoff, K.; Kremling, K. and Ehrhardt, M. (1999). Methods of Sea water analysis, 3rd edition, Weinheim, New York, Wiley-VCH, pp.600. 
Ingole, S.B.; Naik, S.R. and Kadam, G. (2010). Study of phytoplankton of fresh water reservoir at Majalgaon on Sindphana river district beed (M.S.). Inter. Res. J., 1(13): 87-88.

Javed, M. (2006). Studies on metal contamination level in plankton and their role as biological indicator of water pollution in the River Ravi. J. Bio. Sci. 9: 313-317.

Ligeza, S. and Wilk-Wozniak, E. (2011). The occurrence of a Euglene pascheri and Lepocianclis ovurn bloom in an Oxbow Lake in southern Poland under extreme environmental condition. J. Eco. Ind., 11: 925-929.

Maske, S.; Sangolkar, L.N. and Chakrabarti, T. (2010). Temporal variation in density and diversity of cyanobacteria and cyanotoxins in lakes at Nagpur (Maharashatra state), India. Environ. Monit. \& Assess., 169: 299-308.

Mohebbia, M.R.; Saeedi, R.; Montazeri, A.; Vaghefi, K.A.; Labbafi, S.H. and Oktaie, $\mathrm{S}$, et al. (2013). Assessment of water quality in groundwater resources of Iran using a modified drinking water quality index (DWQI). Ecol. Indian; 30:28-34.

Mukherjee, B.; Nivedita, M. and Mukherjee, D. (2010). Plankton diversity and dynamics in a polluted eutrophic lake, Rancki. J. of Enviro. Bio., 31: 827-839.

Perscott, G.W. (1962). Algae of Western Great Lakes area. W.M.C. Brown Co. Inc., Dubque. Iowa. USA.

Perscott, G.W. (1978). How to know freshwater algae. W.M.C. Brown Co. Dubque. Iowa. USA

Piper, C.S. (1947). Soil and Plant Analysis, Interscience Publishers, Inc. New York.

Pradhan, A.; Bhaumik, P.; Das, S.; Mishra, M.; Khanom, S.; Haque, B.A.; Mukherjee, I.; Thakur, A.R. and Chaudhuri, S.R. (2008). Phytoplankton diversity as indicator of water quality for fish cultivation. Amer. Environ. Sci., 4: 406-411.

Radwan, A.M. (1994). Study on the pollution of Damietta Branch and its effects on the phytoplankton. PhD. Thesis. Botany Department, Faculty of Science, Tanta University, 289 PP.

Radwan, A.M.; Tayel, F.T.; Morsy, M.H.; Abdelmoneim, M.A. and Basiony, A.I. (2018). Monitoring of water pollution and eutrophication using phytoplankton as bioindicator in Burullus Lake, Egypt. Mans. J. Environ. Sci., 47(1).

Ramdani, M.; Flower, R.J.; Elkhiati, N.; Kraïem, M.M.; Fathi, A.A.; Birks, H.H. and Patrick, S.T. (2001). North African wetland lakes: characterization of nine sites included in the CASSARINA Project. Aqua. Eco., 35: 281-302.

Rodrigues, A.M.F.; Santos, M.C.R.; Santana, F.J.P. and Sobral, P. (1995). Phytoplankton and Eutrophication of Famous Lake (S. Miguel Islands, Azores)F.( Freshwater).

Sabater, S. and Sabater, F. (1988). Diatoms assemblages in the river Ter. Arch. Hydrobio. 111(3): 397-408.

Samaan, A. (1974). Primary production of Lake Idku. Bull. Nat. Ins. Ocean. \& Fish., ARE, 4:261-317.

Sarwar, S.G. (1996). Epiphytic algal flora attached to Myrophyllum spicatum L. in three Kashmir Lake, India. Enviro. and Biodiv.: in the context of south Asia, 226-231.

Shakweer, L. (2006). Impacts of drainage water discharge on the water chemistry of Lake Idku, Egy. J. of Aqua. Res., 32(1): 264-282

Singh, R.P. and Balasingh, G.S. (2011). Limnological studies of Kodaikanal Lake(Dindugal District), special reference to phytoplankton.

Somani, V.; Gholba, M. and Pejaver, M. (2007). Study of phytoplankton population in Lake Masunda, Thane, employing multivariate analysis. Ecol. Environ. Cons., 13: 847-848. 
Tirkey P.; Bhattacharya T. and Chakraborty S., (2013). Water quality indicesImportant tools for water quality assessment. International Journal of Advances in Chemistry, 1 (1), 15.

Tiwari, A. and Chauhan, S. V. (2006). Seasonal phytoplankton diversity of Kithman Lake, Agra. J. Enviro. Bio.; 27:35-38.

Vinard, W.C. (1979). Diatoms of North America. Text book. New York $3^{\text {rd }}$ Edition, 239.

Wang, Li. B. and Zahang (1993). An evaluating of water pollution and eutrophication in the Dalaihu lake using phytoplankton communities. Acta Hydrobiol. Sin. Shuisheng Shenggu Xue bao, 17, 27-34F (Freshwater).

Zaghloul, F. and Hussien, N. (2000). Impact of pollution on phytoplankton community structure in Lake Idku, Egypt. Nat. Ins. Ocean. \& Fish., ARE, 26: 297-317.

Zebek, E. (2004). Species biodiversity of net phytoplankton as an indicator of trophic changes in the urban lake Jeziorak, Maly. Teka Kom. Ochr. Kszt. Srod. Przyr., I; 316-321.

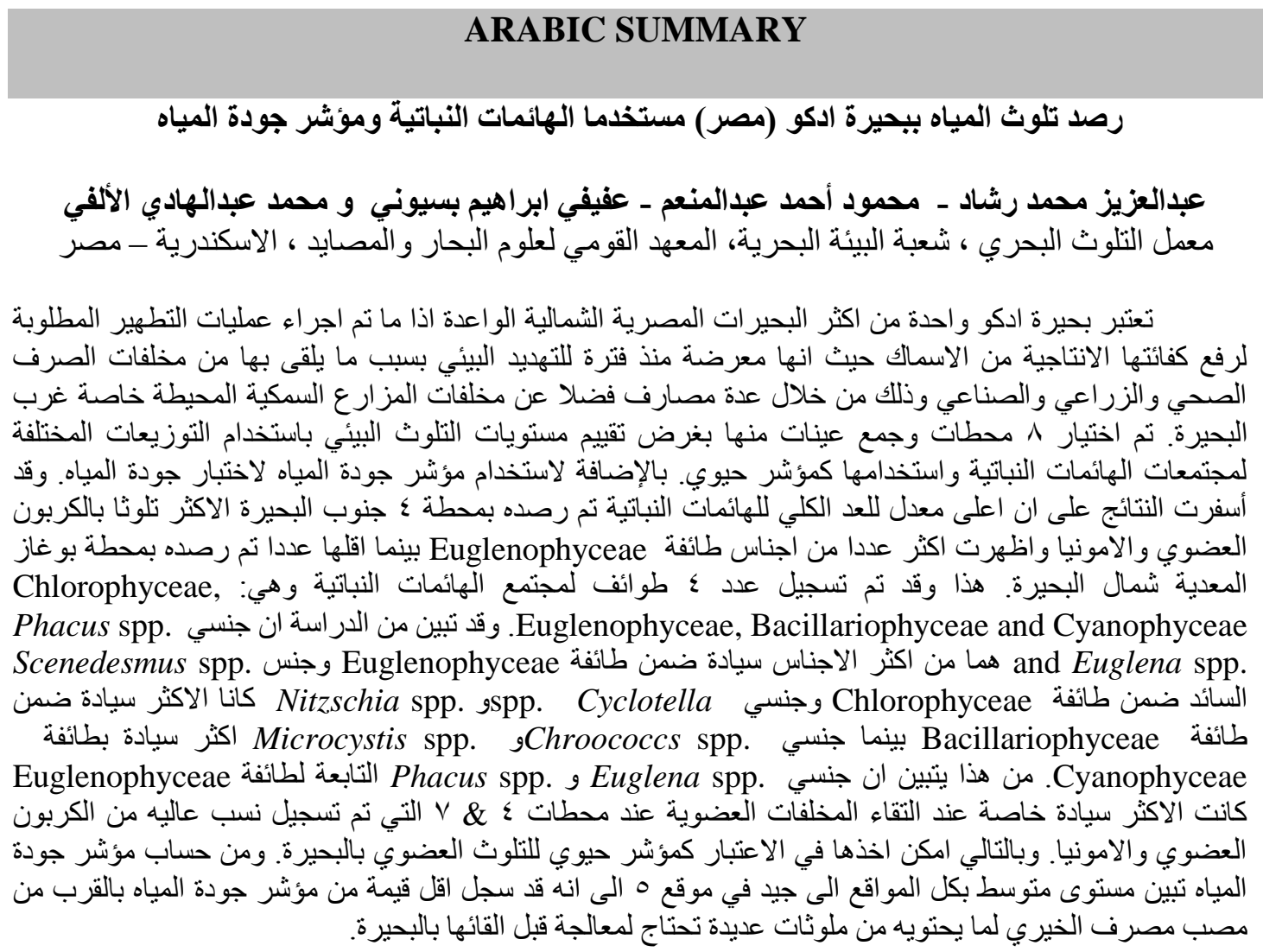

